\title{
Geographic variation of southeastern Pacific intertidal communities
}

\author{
Bernardo R. Broitman ${ }^{1, * *}$, Sergio A. Navarrete ${ }^{1, *}$, Franz Smith ${ }^{1, * * *}$, Steven D. Gaines ${ }^{2}$ \\ ${ }^{1}$ Estación Costera de Investigaciones Marinas, Las Cruces, Departamento de Ecología, P. Universidad Católica de Chile, \\ Casilla 114-D, Santiago, C.P. 6513677, Chile \\ ${ }^{2}$ Department of Ecology, Evolution and Marine Biology, University of California, Santa Barbara, California 93106, USA
}

\begin{abstract}
We conducted field surveys of rocky intertidal communities at 18 sites distributed between $29^{\circ} \mathrm{S}$ and $36^{\circ} \mathrm{S}$ on the coast of central Chile in order to document broad patterns of functional and trophic group abundance and evaluate their association with oceanographic features. Results showed that the main sessile components of the landscape throughout the region were kelps (16\%) and crustose algae (48\%) in the low intertidal zone, while mussels beds (30\%) and corticated algae (32\%) dominated the mid-intertidal zone. Geographic trends in abundance across the entire region varied from no clear regional patterns for some groups (e.g. barnacles), to smooth gradients increasing or decreasing toward higher latitudes for others (kelps and ephemeral algae) and to an abrupt switch from dominant to scarce northward of $32^{\circ} \mathrm{S}$ in 1 group (mussels). Significant among-site negative correlations were detected between the abundances of most algal functional groups and between mussels and barnacles. Herbivore density was negatively correlated with kelp and corticated algal cover, and positively correlated with crustose algal abundance. These correlations reinforce the notion that local biological interactions can partially account for the among-site variability in functional group abundance. We assessed the influence of mesoscale oceanographic features through satellite image analyses, by classifying the study sites as either strongly or weakly influenced by coastal upwelling. At sites strongly influenced by upwelling, we found significantly higher cover of kelps in the low intertidal zone and of corticated algae in the mid-intertidal zone. Cover of ephemeral algae in the mid-intertidal zone was significantly lower at sites strongly affected by upwelling. Contrary to predictions of bottom-up community regulation models, we found no significant differences in abundance of sessile filter feeders (mussels or barnacles), herbivores or carnivores. A significant proportion of the regional variation in abundance in some of the most abundant functional groups within each tidal level was associated with the latitudinal gradient in annual mean sea surface temperature (SST). We detected a significant correlation between SST and the abundance of kelps and crustose algae in the low intertidal zone, and mussels and ephemeral algae in the mid-intertidal zone. The abrupt change in the abundance of mussels in the mid-intertidal zone at about $32^{\circ} \mathrm{S}$ may indicate a similarly abrupt change in biological or environmental conditions. Lack of significant correlation between the abundance of mussels and other functional groups suggests that biological interactions may not be responsible for this geographic discontinuity. We suggest that oceanography may be largely involved in the geographic variability detected in patterns of community structure. Recent remote sensing studies documenting oceanographic discontinuities around the $32^{\circ} \mathrm{S}$ zone support our suggestion. Our results highlight the need for further experimental and oceanographic studies in areas where strong biophysical gradients are observed. Such areas may well reflect the existence of steep oceanographic gradients sensitive to large-scale environmental forcing.
\end{abstract}

KEY WORDS: Community structure $\cdot$ Functional groups $\cdot$ Regional variation $\cdot$ Upwelling $\cdot$ Nearshore oceanography

*Corresponding author. E-mail: snavarre@genes.bio.puc.cl

Present addresses:

**Department of Ecology, Evolution and Marine Biology, University of California, Santa Barbara, California 93106, USA

${ }^{* * *}$ Charles Darwin Foundation, Puerto Ayora, Isla Santa Cruz, Galapagos, Ecuador

\section{INTRODUCTION}

Characterization of processes operating at different spatial and temporal scales and how these processes interact to form ecological patterns has become a 
central focus in contemporary ecological research (Ricklefs 1987, Levin 1992). Over small (local) spatial scales of $O\left(1\right.$ to $\left.100 \mathrm{~m}^{2}\right)$, experimental manipulation has provided considerable insight into local ecological dynamics (e.g. Connell 1974, Paine et al. 1985, Menge 1992, Navarrete 1996), while traditional biogeographic studies at larger scales of $O\left(10^{2}\right.$ to $\left.10^{3} \mathrm{~km}\right)$ have provided perspectives of the processes influencing whole assemblages (e.g. Santelices 1980, Gaines \& Lubchenco 1982, Brättstrom \& Johänssen 1983, Bustamante \& Branch 1996, Brown \& Lomolino 1998). Between local and biogeographic scales, there is a suite of processes the effects of which on patterns of community composition and species abundance are apparent only when sites spread over $O(10$ to $100 \mathrm{~km})$ are compared (Gaines \& Bertness 1992, Bustamante et al. 1995a,b, Archambault \& Bourget 1996, Menge et al. 1997a,b, Archambault et al. 1999, Leonard 2000). These processes have only recently begun to receive the attention of marine ecologists and have yet to be integrated with information derived from local and biogeographic studies (Menge \& Olson 1990, Connolly \& Roughgarden 1998). Analyses of processes across this spatial scale (i.e. mesoscale) hold the promise of providing a framework with which results of localscale studies could be used to make predictions about community responses across large-scale environmental gradients.

Local-scale experimental studies in several comparable geographic locations (i.e. temperate rocky shores) have generated numerous testable hypotheses regarding how interspecific interactions determine temperate rocky intertidal community structure. For example, at low tidal levels, experimental manipulations have demonstrated the existence of strong competitive interactions between corticated algae and kelps, whereby both functional groups can be the dominant space occupiers over crustose algal forms (e.g. erect fleshy algae over encrusting calcified algae; see Lubchenco \& Gaines 1981, Santelices 1990, Steneck \& Dethier 1994, for reviews). Competitive hierarchies can be altered by herbivory. Under high consumer pressure, crustose algae (mostly calcified forms) replace kelps or corticated algae as the dominant space occupiers in the low intertidal zone (Lubchenco \& Gaines 1981, Sousa et al. 1981, Branch \& Moreno 1994). Experimental manipulations have repeatedly demonstrated that mussels can be the dominant competitors for space at mid tidal levels, capable of smothering and excluding algae and other sessile organisms from the primary substratum (e.g. Paine 1966, Menge 1976, Paine et al. 1985, Navarrete \& Castilla 1990b, Menge et al. 1994). The abundance of dominant sessile functional groups can also be modulated by carnivores, through cascading top-down effects of seastars and predatory gastropods (Paine 1974, Menge 1976, Castilla \& Durán 1985, Paine et al. 1985, Castilla \& Paine 1987, Navarrete 1996, Navarrete \& Menge 1996).

Over continental scales, patterns of functional group abundance have been suggested to vary following environmental gradients, such as the latitudinal variation in solar irradiation (e.g. Gaines \& Lubchenco 1982, Brown \& Lomolino 1998). However, very few empirical tests of patterns of intertidal community structure have been carried out over continental scales (Bustamante et al. 1995b, Bustamante \& Branch 1996). In contrast, several recent studies have demonstrated that mesoscale oceanographic processes, acting over $O(10$ to $100 \mathrm{~km})$, can influence the local dynamics of marine populations and communities (Bertness et al. 1991, Menge 1992, 1997a, Menge et al. 1994, 1997a, Bustamante et al. 1995a). These studies have led to the hypothesis that differences in nutrients and/or chlorophyll concentrations, forced by the upwelling of cooler, nutrient-rich waters typical in eastern boundary current systems (Hill et al. 1998), strongly influence the local dynamics of intertidal assemblages (Bustamante et al. 1995b, Menge et al. 1997a,b). Similarly, offshore Ekman transport generated during upwelling events and their subsequent relaxation, is an important oceanographic process determining temporal and spatial variability in recruitment rates (Gaines \& Roughgarden 1985, Roughgarden et al. 1988, Farrell et al. 1991, Alexander \& Roughgarden 1996). Variability in the strength of offshore Ekman transport has been proposed to create a gradient in propagule supply of competitively dominant sessile species, accounting for differences in broad patterns of community structure between the coasts of northern California and Oregon (Connolly \& Roughgarden 1998, 1999a,b).

The shoreline of central Chile, between $26^{\circ} \mathrm{S}$ and $40^{\circ} \mathrm{S}$ latitude, provides an excellent opportunity to evaluate the relative importance of local-, meso- and regional-scale processes on intertidal community structure. The region is an east boundary upwelling ecosystem with a characteristic offshore, equatorward, flowing current (Peru-Chile current system; Strub et al. 1998). A gradient in solar irradiation is evident in patterns of annual mean sea surface temperature (SST), which shows a monotonic decrease towards higher latitudes (Fig. 1a). At the mesoscale, several persistent upwelling centers have been reported centered at 30 , $32,33,36$ and $37^{\circ} \mathrm{S}$, mostly associated with coastal topography (Johnson et al. 1980, Bernal et al. 1982, Fonseca \& Farías 1987, Montecinos \& Balbontin 1993, Montecino et al. 1996, Longhurst 1998, Strub et al. 1998, Thomas 1999). At local scales, experimental studies have shown the importance of interspecific competition (Ojeda \& Santelices 1984, Navarrete \& 
Fig. 1. (a) Annual average $( \pm \mathrm{SE})$ sea surface temperature (SST) over square degrees of latitude, calculated from onboard $0 \mathrm{~m}$ observations for the period 1930 to 1991 (SHOA 1996). A latitudinal decrease in the mean and maximum SST is evident towards higher latitudes; (b) NOAA-AVHRR satellite image from November 14, 1992, depicting the presence of numerous upwelling centers along the region surveyed. Lines point out the locations of intertidal field sites surveyed
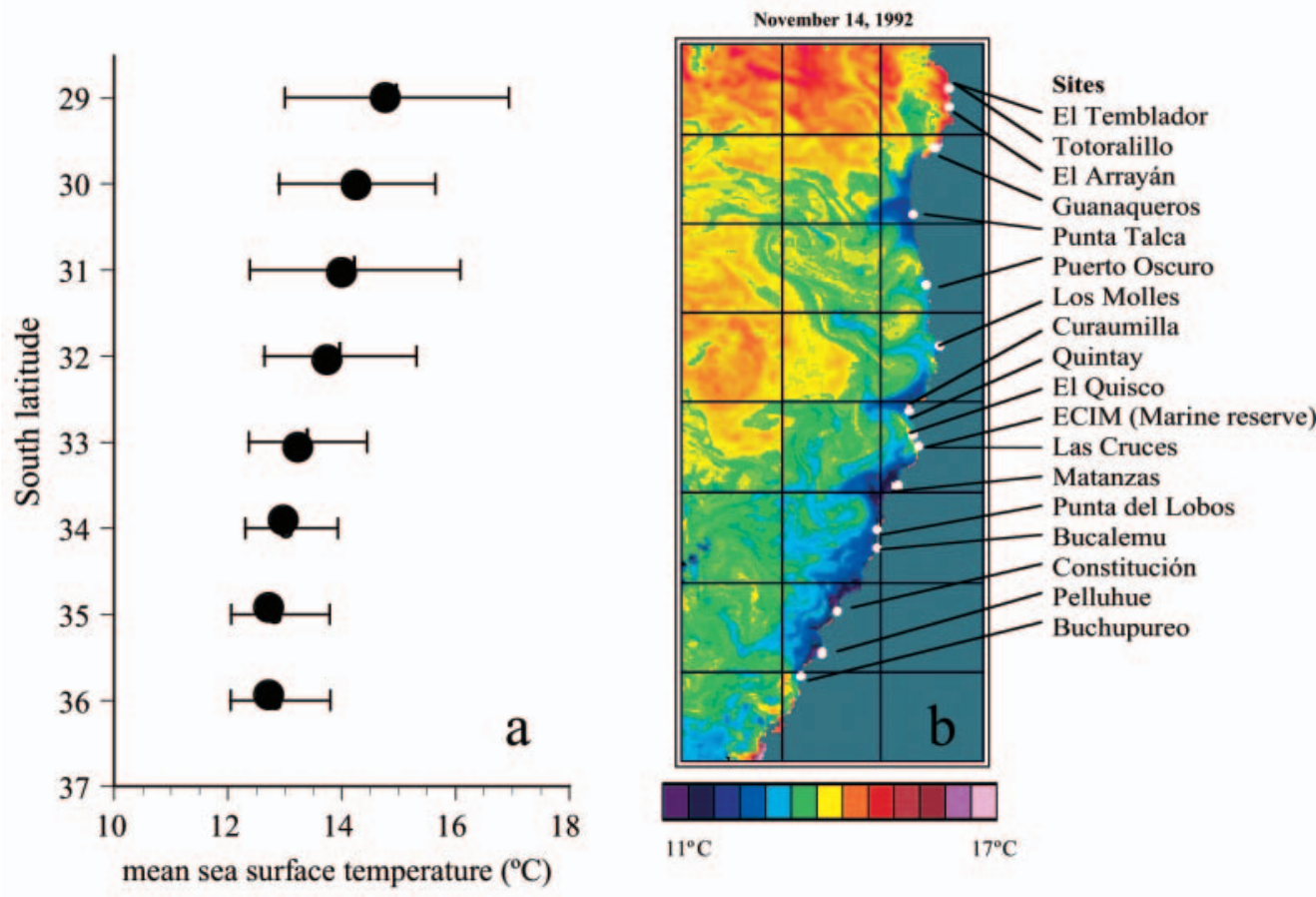

Castilla 1990a), herbivory (Jara \& Moreno 1984, Castilla \& Durán 1985, Oliva \& Castilla 1986) and predation (Castilla 1981, Castilla \& Durán 1985, Castilla \& Paine 1987). Another important factor affecting Chilean littoral communities is the human exploitation of fish, invertebrates and macroalgae, which can have dramatic effects on the intertidal landscape (Moreno et al. 1986, Castilla 1993, 1999, Botsford et al. 1997).

Despite a growing understanding of the general dynamics of coastal upwelling ecosystems, few studies have examined the importance of associated bottomup forces (e.g. nutrients, phytoplankton concentration) on Chilean coastal ecosystems (but see Bosman et al. 1987, Moreno et al. 1998, Vásquez et al. 1998). Even fewer studies have characterized the spatial and temporal variability of coastal upwelling centers (Strub et al. 1998). In the current study, we present geographic patterns of the structure of rocky intertidal communities along $8^{\circ}$ of latitude, as a descriptive part of a longterm study on the dynamics of nearshore marine ecosystems. We examine geographic variation in community structure in relation to patterns of functional group abundances and regional and mesoscale coastal oceanography. Our purpose is to provide a number of testable hypotheses that could be evaluated with further comparative and experimental investigations. We hope that this approach could form the basis of a predictive framework in which local interspecific interactions and patterns of physical forcing can be integrated to identify the main determinants of regional patterns of community structure.

\section{METHODS}

Study sites and community structure surveys. We conducted quantitative surveys of low and mid-intertidal assemblages at 18 rocky intertidal sites spaced roughly $0.5^{\circ}$ of latitude apart, between 29 and $36^{\circ} \mathrm{S}$ (Fig. 1b). In the northern part of the study region, 3 sites were located on the coastline within latitude $29^{\circ} \mathrm{S}$ (El Temblador, Totoralillo Norte and El Arrayán), 2 sites within $30^{\circ} \mathrm{S}$ (Guanaqueros and Punta Talca), 1 within $31^{\circ} \mathrm{S}$ (Puerto Oscuro), and 1 within $32^{\circ} \mathrm{S}$ (Los Molles). Near $33^{\circ} \mathrm{S}$, sampling was more intensive with 6 sites less than $30 \mathrm{~km}$ apart (Curaumilla, Quintay, El Quisco, ECIM (marine reserve, Estación Costera de Investigaciones Marinas), Las Cruces (outside marine reserve) and Matanzas. In the southern part of the region, 2 sites were located within $34^{\circ} \mathrm{S}$ (Punta de Lobos and Bucalemu), 2 within $35^{\circ} \mathrm{S}$ (Constitución and Pelluhue), and one within $36^{\circ} \mathrm{S}$ (Buchupureo).

Preliminary surveys of the majority of these study sites were conducted during austral winter 1997 to develop standard sampling methodologies and generate preliminary lists of species with reference collections (data not presented). Data presented here consist of surveys of all sites during 2 low tides in austral summer (December 1997 to March 1998) and winter (June to August 1998), except El Temblador (only winter 1998). Hazardous swell precluded the survey of the mid-zone of Quintay in summer, the low zone of Totoralillo Norte in winter and the low and mid-zones 
of the latter site during summer (note the data missing in Figs 2 and 4a).

Among-site heterogeneity of local physical conditions was minimized by selecting, wherever possible, gently sloping benches $\left(20\right.$ to $30^{\circ}$ ) of similar morphology fully exposed to prevailing southwestern swell. Bench dimensions varied among sites, but were never smaller than $\sim 30 \times 5 \mathrm{~m}$ in horizontal and vertical extent respectively. The heterogeneity in bench sizes stems from the rugged topography of the exposed rocky shore in central Chile, where intertidal benches of appropriate morphology (i.e. flat) are either scarce or extremely hazardous to sample. Tidal heights selected for sampling were determined using the pervasive zonation features of the central Chilean rocky intertidal: a band of the large brown kelp Lessonia nigrescens in the low zone (ca $0.5 \mathrm{~m} \mathrm{MLW)} \mathrm{and} \mathrm{extensive}$ cover of macroalgae and/or mussel beds in the midzone (ca $1.0 \mathrm{~m} \mathrm{MLW),} \mathrm{which} \mathrm{were} \mathrm{present} \mathrm{at} \mathrm{all} \mathrm{sites.}$ We did not sample the high intertidal zone because of time constraints. However, the sampling design included the tidal heights at which the greatest diversity and abundance of sessile and mobile organisms are encountered.

Table 1. Percentage of variance accounted for by each of the spatial scales examined for winter 1998 data. Variance is shown for the main functional groups proposed in this study. Note that, except for mobile consumers, a low percentage of the variation is accounted for by the quadrat (within bench) and bench (within site) scale

\begin{tabular}{|c|c|c|c|}
\hline Low intertidal zone & $\%$ & Mid-intertidal zone & $\%$ \\
\hline Kelps & & Mussels & \\
\hline Site & 91.63 & Site & 94.43 \\
\hline Bench & 0 & Bench & 3.98 \\
\hline Quadrat & 8.37 & Quadrat & 1.59 \\
\hline Corticated algae & & Corticated algae & \\
\hline Site & 75.66 & Site & 83.53 \\
\hline Bench & 18.04 & Bench & 10.5 \\
\hline Quadrat & 6.3 & Quadrat & 5.97 \\
\hline Crustose algae & & Crustose algae & \\
\hline Site & 91.69 & Site & 85.91 \\
\hline Bench & 2.4 & Bench & 8.19 \\
\hline Quadrat & 5.91 & Quadrat & 5.9 \\
\hline Ephemeral algae & & Ephemeral algae & \\
\hline Site & 88.99 & Site & 74.78 \\
\hline Bench & 2.92 & Bench & 16.87 \\
\hline Quadrat & 8.09 & Quadrat & 8.35 \\
\hline Herbivores & & Herbivores & \\
\hline Site & 73.66 & Site & 86.55 \\
\hline Bench & 8.66 & Bench & 8.11 \\
\hline Quadrat & 17.68 & Quadrat & 5.34 \\
\hline Carnivores & & Carnivores & \\
\hline Site & 64.11 & Site & 41.48 \\
\hline Bench & 0 & Bench & 40.52 \\
\hline Quadrat & 35.89 & Quadrat & 18 \\
\hline
\end{tabular}

A minimum of 8 and a maximum of 22 quadrats of $0.25 \mathrm{~m}^{2}$ were haphazardly placed along 10 to $30 \mathrm{~m}$ long horizontal transects at mid- and low tidal heights along 1 rocky bench during summer 1998. In a subset of sites, a second bench 20 to $80 \mathrm{~m}$ away was included in winter 1998 to ensure adequate documentation of local community patterns. A nested analysis of variance (quadrats within benches and benches within sites) showed that a large proportion of the variation in abundance of individual functional groups was due to among-site differences, particularly for the main sessile groups (Table 1). Based on this result, bench data for each site were pooled to concentrate on regional trends. Similarly, as we did not observe a coherent seasonal response in the main sessile groups, data from summer and winter surveys were pooled to concentrate on regional trends. For each quadrat, we visually estimated percentage cover of macroscopic sessile flora and fauna with the aid of a monofilament grid of twenty-five $10 \times 10 \mathrm{~cm}$ squares (i.e. $4 \%$ cover each). This sampling method provided an adequate and consistent estimate of abundance of common species (Dethier et al. 1993), but was less accurate for species of low cover (i.e. $<2$ to $4 \%$; Bustamante 1997). Due to time constraints, and because we wanted to get an estimate of total abundance, we did not distinguish between primary (on the rock surface) and secondary (on other organisms) cover of invertebrates and algae. We did distinguish between canopy cover of erect brown algae (i.e. kelps) and the primary cover of their holdfasts. Therefore, except for bare rock and kelp holdfast, cover estimates reflect total abundance of each individual species at a given site (i.e. cover could exceed $100 \%$ ) and not necessarily occupancy of primary substrate.

Densities of all mobile invertebrates, including obligate epiphytic species (Scurria scurra), were obtained by counts of individuals within the $0.25 \mathrm{~m}^{2}$ quadrat. Small limpets occurring at high densities, such as Siphonaria lessoni and Scurria spp., were subsampled in a fixed $0.04 \mathrm{~m}^{2}$ quadrat in the top left corner of each larger quadrat. Because of their sparse distribution and large size, density estimates of the seastars Heliaster helianthus were obtained through transect counts across the entire bench (of variable length and always $1 \mathrm{~m}$ wide), and are presented separately from other carnivore species.

Due to the widespread human harvesting in the intertidal zone of central Chile, it was difficult to assess the degree of this impact at each of the study sites, with the exception of the marine reserve site (ECIM), where human harvesting has been excluded since 1982 (Castilla 1999). The assumption that all other sites are impacted to a similar degree is based on observations over numerous field seasons, where activity of inter- 
tidal fishermen was recorded on nearly every sampling date at all sites surveyed (Broitman \& Navarrete unpubl. obs.).

Taxonomy and functional groupings. To quantify broad compositional patterns of intertidal assemblages across the region, we examined species abundances pooled into functional groups (Table 1). The classification that we employed in the present study follows the main resource use strategies of the taxonomic entities encompassed by each functional group. Groupings are morphological, taxonomical or trophic, but tend to capture the ecosystem function the groups perform (Padilla \& Allen 2000). Mobile invertebrate species (i.e. consumers) were grouped according to trophic position (carnivores and herbivores), based on their reported diets (Castilla 1981, Castilla \& Paine 1987, Soto 1996). Sessile invertebrates (benthic filter-feeders) were classified by taxonomy, as it represents prevalent competitive hierarchies in space-use patterns (mussels and barnacles). Algae classification mainly follows Steneck \& Dethier's (1994) scheme, although we combined some of their functional groups under single ones, after confirming that separately they followed similar trends (foliose and filamentose algae under ephemeral algae, and fleshy and calcified crustose algae under crustose algae). Our algal classification scheme largely encompasses the distinctive ecological patterns commonly observed in the Chilean intertidal ecosystem, where a few species account for a large proportion of the landscape pattern (see 'Results'). Due to taxonomic uncertainties in the field and to avoid destructive sampling, some species were combined as genera in the analysis, providing an underestimate of species richness.

Data analysis. As a first step towards examining the role of local interspecific interactions as a structuring agent within these communities, we measured the degree of correlation (Spearman's rank, $r_{S}$ ) among the local abundances of sessile functional groups. In this case, rank correlations were preferred over parametric correlations because we were interested in simple trends of the form: 'where there are more predators there are less prey'. Correlations between sessile functional groups and herbivores employed functional group abundances within each tidal height separately (i.e. see Fig. 4a,b). Carnivore abundance data were pooled across tidal heights, due to their low densities and high mobility over the tidal range examined.

To evaluate the influence of mesoscale physical processes, we classified our study sites as strongly or not strongly influenced by local coastal upwelling. The classification followed results from analysis of 15 NOAA-AVHRR (National Oceanic and Atmospheric Administration-Advanced Very High Resolution Ra- diometer) SST images, available through the upwelling season of 1992/1993 (austral spring to summer). As a simple means of classification of upwelling sites, we calculated the difference between SST roughly $2 \mathrm{~km}$ offshore with that $\sim 25 \mathrm{~km}$ and $\sim 50 \mathrm{~km}$ offshore. For a given site, a consistent and significant negative SST differential $(50 \mathrm{~km} \mathrm{SST}$ and $25 \mathrm{~km} \mathrm{SST} \mathrm{minus} 2 \mathrm{~km}$ SST) over all images analyzed at the 3 different spatial resolutions (25,50 and 100 pixels) was interpreted as the presence of cold water advected by coastal upwelling near the coast in front of the site. A homogeneous pattern of inshore-offshore SST (difference close to 0) or warmer inshore water was considered as evidence of weak upwelling. Classification of sites through satellite images has been corroborated by temperature records from in situ temperature loggers deployed at 10 of the study sites for the past 3 yr (Navarrete unpubl. data). Using a 1-way ANOVA, we compared functional group abundance patterns according to the influence of coastal upwelling across sites.

To examine regional trends in abundance, we performed rank-order correlations of local functional group abundances and SST. Rank-correlation analyses were chosen after visual inspection of normal probability plots of arcsine and square-root transformed data still evidenced large departures from normality. Historical annual mean SST was calculated from data on monthly means (1930 to 1991), available over square degrees of latitude from on-board $0 \mathrm{~m}$ measurements (SHOA 1996). A highly significant relationship was observed between latitude and SST $\left(\mathrm{r}^{2}=\right.$ $-0.93, \mathrm{p}<0.0001, \mathrm{n}=8$ ) within the region examined $\left(29\right.$ to $\left.36^{\circ} \mathrm{S}\right)$. A consequence of the collinearity between SST and latitude is that statistical analyses performed through correlations with SST yield identical conclusions with latitude. Following this result, trends in abundance presented in relation to SST are interchangeably interpreted as geographic trends in the 'Results' section (i.e. negative correlations with SST represent southward increases in abundance). LOWESS smoothing on SST-functional group abundance scatterplots was utilized to explore geographical structure in abundance patterns (Neter et al. 1996, Legendre \& Legendre 1998). We only present results of correlations with SST, as we considered temperature a more biologically meaningful variable than geographic position. Low SST is also coupled to increased nutrient and pigment concentrations (Dayton et al. 1999, Goes et al. 2000) and is associated with long- and cross-shelf advection of surface waters (Hill et al. 1998, Longhurst 1998). The site within the marine reserve (ECIM) was not included in these analyses, since patterns of community structure at this site are known to be notably different due to the exclusion of intertidal fishers (Castilla 1999). 
Table 2. List of identified genera assigned to the different functional and trophic groups considered. Numbers in parentheses indicate the number of species for a given genus (see 'Methods' for details)

\begin{tabular}{|llll|}
\hline Kelps & Crustose algae & Mussels & Carnivores \\
Durvillaea (1) & Hildenbrandia (1) & Brachidontes (1) & Concholepas (1) \\
Lessonia (1) & Lithothamnion (1) & Perumytilus (1) & Nucella (2) \\
Corticated algae & Ralfsia (1) & Semimytilus (1) & Acanthocyclus (2) \\
Adenocystis (2) & Ephemeral algae & Barnacles & Heliaster (1) \\
Ahnfeltia (1) & Bryopsis (2) & Austromegabalanus (1) & Stichaster (1) \\
Ahnfeltiopsis (1) & Ceramium (1) & Balanus (1) & Herbivores \\
Chondrus (1) & Chaetomorpha (1) & Nothobalanus (1) & Acanthopleura (1) \\
Codium (2) & Cladophora (1) & Jhelius (1) & Chaetopleura (1) \\
Colpomenia (3) & Ectocarpus (1) & Nothochthamalus (1) & Chiton (3) \\
Dendrymenia (1) & Grateloupia (1) & & Enoplochiton (1) \\
Gelidium (3) & Polysiphonia (1) & & Tonicia (3) \\
Glossophora (1) & Rhizoclonium (2) & & Fissurella (8) \\
Gymnogongrus (1) & Cryptonemia (1) & & Scurria (10) \\
Halopteris (1) & Enteromorpha (1) & & Siphonaria (1) \\
Laurencia (1) & Petalonia (1) & & Tegula (1) \\
Mazzaella (1) & Porphyra (1) & & \\
Montemaria (1) & Scythosiphon (1) & & \\
Nothogenia (1) & Ulva (1) & & \\
Prionitis (1) & Articulated algae & & \\
Rhodymenia (1) & Corallina (1) & & \\
Sarcothalia (1) & & & \\
Schottera (1) & & & \\
Trematocarpus (1) & & & \\
\hline
\end{tabular}

accounted for $11.5 \%$ of the low intertidal cover. Less abundant functional groups (percentage cover) in the low zone were barnacles $(4.2 \%$, not shown), ephemeral algae (1.6\%) and bare rock $(5.4 \%)$, although at 2 high-latitude sites bare rock reached almost 30\% levels (Fig. 2e).

Across the study region, kelps increased in primary (holdfast) cover toward the south $\left(\mathrm{r}_{\mathrm{S}}=\right.$ -0.776 , p < 0.001), particularly south of Matanzas, at $34^{\circ} 58^{\prime} \mathrm{S}$ (Fig. 2a). Corticated algae showed more abrupt changes in cover, generally increasing towards the south $\left(\mathrm{r}_{\mathrm{S}}=-0.437, \mathrm{p}\right.$ $>0.05)$, but at least 2 northern and 1 central site had exceptionally high cover of Gelidium spp. (El Temblador, Guanaqueros, El Quisco; Fig. 2b). Cover of crus-

\section{RESULTS}

In these surveys, 101 putative species (of which 92 were actually identified to species), belonging to 62 genera were recorded (Table 2). Numerically, richness of sessile species was dominated by macroalgae and the mobile assemblage by gastropods. A more detailed analysis of species richness and species composition within the region will be presented elsewhere.

\section{Patterns of functional group abundance}

In terms of individual functional groups, kelps (Lessonia and Durvillaea antarctica) and crustose algae (mostly Hildenbrandia and Lithothamnion) were the most conspicuous components of the low intertidal landscape (Fig. 2). Another important component of primary and secondary cover in the low zone was corticated algae (mostly Gelidium spp.), which on average

Fig. 2. Mean percentage cover $( \pm \mathrm{SE})$ of dominant sessile functional groups of the low intertidal zone: (a) kelps, (b) corticated algae, (c) crustose algae, (d) ephemeral algae, and (e) percentage cover of bare rock. Please note that different $y$-axis scales are used. The solid bar indicates the marine reserve (ECIM) site. The shaded background indicates sites strongly influenced by coastal upwelling. Satellite image analyses were inconclusive only in the case of Constitución. Sites are listed from north (left) to south (right)
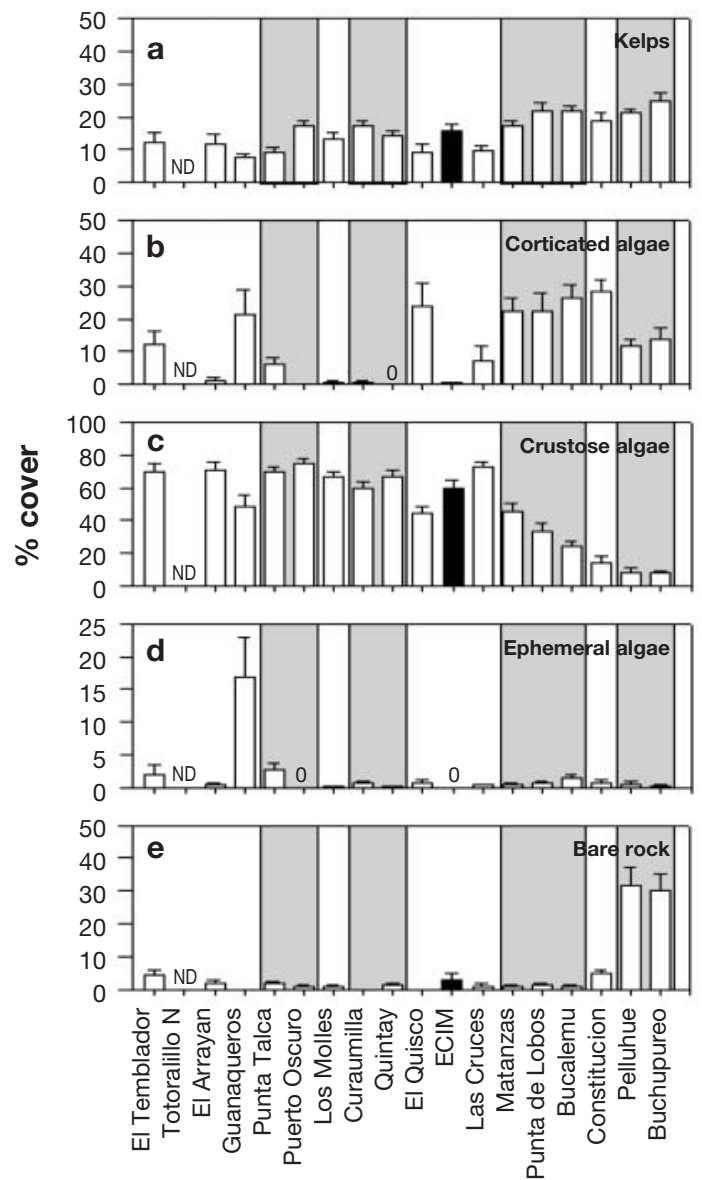

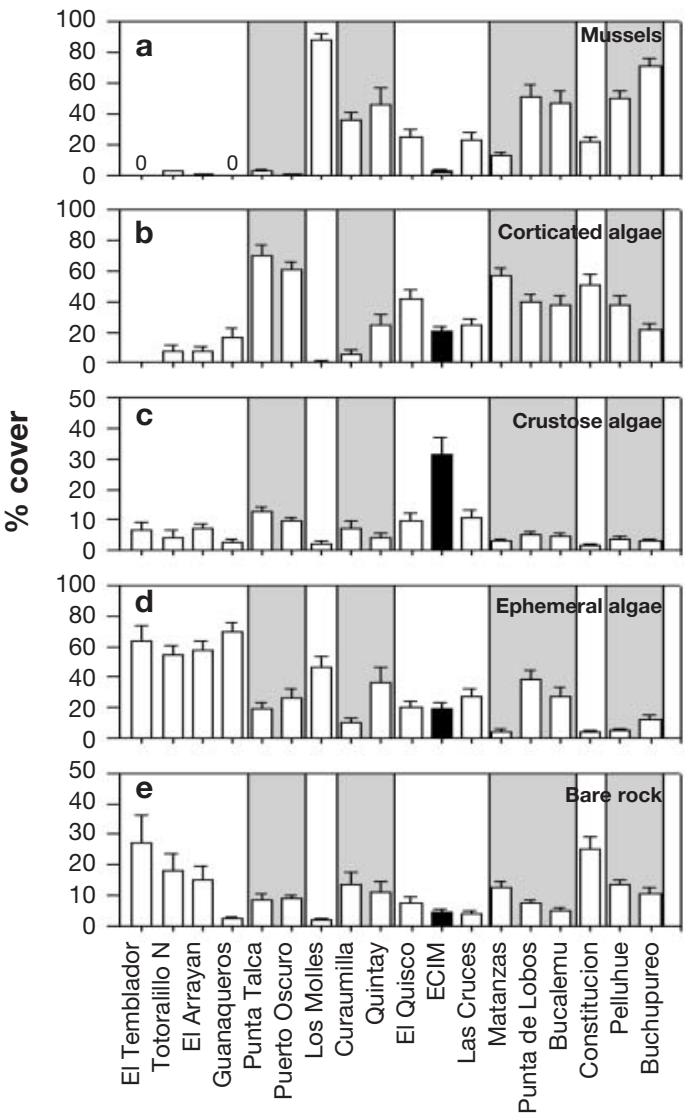

Fig. 3. Mean percentage cover $( \pm \mathrm{SE})$ of dominant sessile functional groups of the mid-intertidal zone: (a) mussels, (b) corticated algae, (c) crustose algae, (d) ephemeral algae, and (e) percentage cover of bare rock. Please note the different $y$-axis scales used. See Fig. 2 legend for details

tose algae was high (over $50 \%$ ) at most sites, but a sharp decrease was observed south of Matanzas $\left(\mathrm{r}_{\mathrm{S}}=\right.$ 0.810, p < 0.001; Fig. 2c). Ephemeral algae cover was generally very low and peaked in abundance at 1 site (Guanaqueros; Fig. 2d). Bare rock cover showed no clear trend across the region $\left(\mathrm{r}_{\mathrm{S}}=-0.493, \mathrm{p}>0.05\right.$; Fig. 2e). The high bare rock availability observed in the southernmost sites is probably due to periodic sand abrasion (Broitman pers. obs.).

In the mid-intertidal zone, mussel beds $(27.9 \%$, mostly Perumytilus purpuratus) and/or rhodophycean corticated algal species (29.6\%, mostly Mazzaella laminarioides) dominated the primary and secondary cover (Fig. 3). Other abundant components of the mid-intertidal landscape were ephemeral algae, which occupied an average of $26.8 \%$ primary and secondary cover. Barnacles (not shown) with $7.2 \%$, crustose algae with $6.9 \%$, and bare rock with $10.6 \%$ were less prominent components of the mid-intertidal zone when averaged across the study region (Fig. 3).
Perhaps the most abrupt change in the intertidal landscape across the region occurred in the mid-zone, where mussels changed from being the dominant sessile component of the community south of Los Molles $\left(32^{\circ} 23^{\prime} \mathrm{S}\right)\left(\mathrm{r}_{\mathrm{S}}=-0.740, \mathrm{p}<0.002\right)$, to scattered individuals north of this site (Fig. 3a). The only exception to the mussel-dominated mid-intertidal zone south of Los Molles was found within the marine reserve (ECIM site; solid bar in Fig. 3a). Another discontinuous change in abundance was observed in corticated algae, which generally achieved higher cover southward from Quintay $\left(33^{\circ} 11^{\prime} \mathrm{S}\right)$, reaching on average over $40 \%$ cover, compared to less than $20 \%$ at most sites north of Los Molles $\left(r_{S}=-0.344, p>0.05\right)$. Exceptions to this pattern were 2 sites in the north (Punta Talca and Puerto Oscuro; Fig. 3b), where cover of corticated foliose algae reached over $60 \%$. Crustose algae showed overall low abundance at this tidal elevation, with no clear trend across the region $\left(\mathrm{r}_{\mathrm{S}}=0.344, \mathrm{p}>\right.$ 0.05), and a local peak within the ECIM (Fig. 3c, solid bar). Ephemeral algal cover (mostly Ulva spp. and Porphyra columbina) generally increased towards the north $\left(\mathrm{r}_{\mathrm{S}}=0.674, \mathrm{p}<0.01\right)$, reaching a maximal cover of
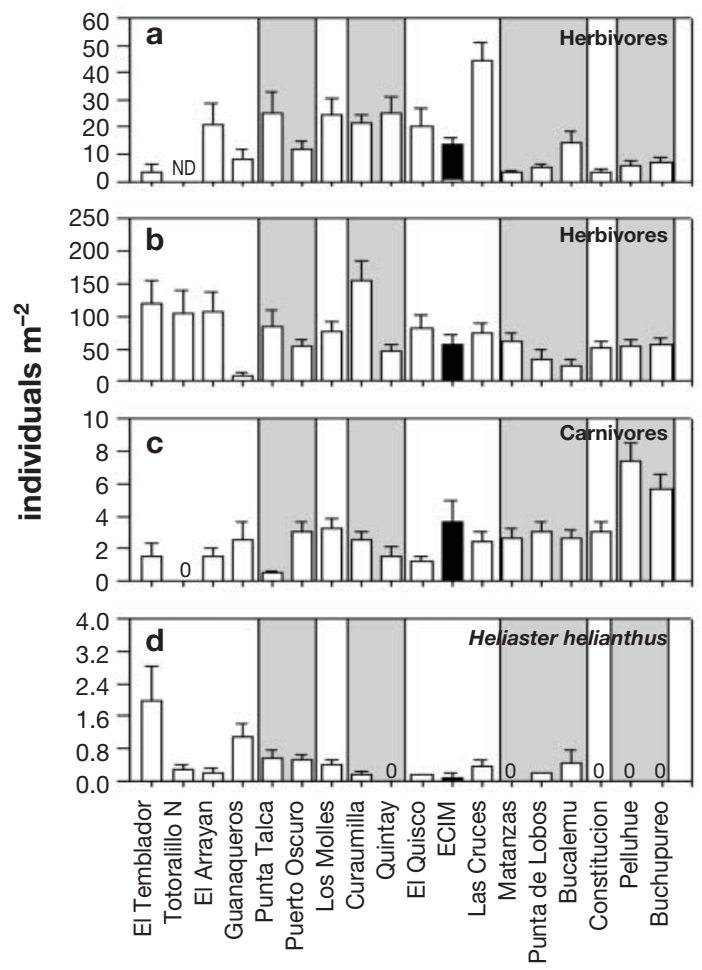

Fig. 4. Mean density per square meter $( \pm \mathrm{SE})$ of (a) herbivores in the low intertidal zone, (b) herbivores in the mid-intertidal zone, (c) carnivores pooled for the mid- and low intertidal zones, and (d) the predatory seastar Heliaster helianthus. Herbivore and carnivore densities were quantified through quadrat censuses, while seastars were counted along transects of variable length. See 'Methods' and Fig. 2 legend for details 
over $60 \%$ north of Punta Talca (Fig. 3d). Bare rock showed overall low cover across the region $\left(\mathrm{r}_{\mathrm{S}}=0.124\right.$, $\mathrm{p}>0.05$ ), with higher values at some but not all northern sites and at 1 southern site (Fig. 3e).

The numerically dominant herbivore groups across the low and mid-intertidal zones were patellid gastropods (47.3 and $65.7 \%$, in the low and mid-intertidal zones, respectively), chitons (29.6 and 9.6\%) and fissurellids (11.8 and 4.\%). Densities across the region showed a slight decline in abundance at the low intertidal zone of sites from Matanzas southward $\left(\mathrm{r}_{\mathrm{S}}=\right.$ 0.171, p > 0.05; Fig. 4a). An opposite trend was observed in the mid-intertidal zone $\left(\mathrm{r}_{\mathrm{S}}=-0.379, \mathrm{p}>\right.$ 0.05; Fig. 4b). Across tidal levels, there was a more than 10-fold increase in herbivore density from the low to the mid-intertidal zones (Fig. 4a,b), mostly due to the presence of small limpets (i.e. $<1 \mathrm{~cm}$ shell length) at mid-levels.

Overall, juveniles of the muricid gastropod Concholepas concholepas (<4 cm peristomal length) and 2 species of Acanthocyclus crabs numerically dominated the carnivore group. No consistent trend in abundance across the region was detected for tidal heights pooled together (Fig. 4C, see 'Methods' for details). A general southward declining trend was observed for the seastar Heliaster helianthus $\left(\mathrm{r}_{\mathrm{S}}=\right.$ 0.590, p < 0.02), marked by a rather abrupt absence south of the Bucalemu site $\left(35^{\circ} 40^{\prime} \mathrm{S}\right.$, Fig. $\left.4 \mathrm{~d}\right)$, as the species approaches its southern geographic limit (ca $37^{\circ} \mathrm{S}$; Castilla 1981).

Table 3. Correlations (Spearman's rank, $\mathrm{r}_{\mathrm{S}}$ ) between functional and trophic group abundances across the 18 sites surveyed. Only the more abundant (i.e. accounting for $>70 \%$ of total cover) sessile groups within each tidal height were considered, a dash indicates where the functional group was too scarce in a given tidal level for meaningful correlations $\left({ }^{* * *} \mathrm{p}<0.005,{ }^{* *} \mathrm{p}<0.01,{ }^{*} \mathrm{p}<0.05\right)$

\begin{tabular}{|c|c|c|c|c|c|c|}
\hline \multicolumn{7}{|l|}{ Low intertidal zone } \\
\hline Corticated algae & 0.25 & & & & & \\
\hline Crustose algae & $-0.63^{* * *}$ & $-0.66^{* * *}$ & & & & \\
\hline Ephemeral algae & - & - & - & & & \\
\hline Mussels & - & - & - & - & & \\
\hline Barnacles & -0.13 & -0.19 & -0.21 & - & - & \\
\hline Herbivores & $-0.50^{*}$ & $-0.57^{* *}$ & $0.56^{* *}$ & - & & \\
\hline Carnivores & & & & & 0.08 & -0.42 \\
\hline \multicolumn{7}{|l|}{ Mid-intertidal zone } \\
\hline Corticated algae & - & & & & & \\
\hline Crustose algae & - & 0.16 & & & & \\
\hline Ephemeral algae & - & $-0.52^{*}$ & 0.05 & & & \\
\hline Mussels & - & -0.01 & -0.38 & -0.22 & & \\
\hline Barnacles & - & -0.41 & 0.09 & 0.13 & $-0.49^{*}$ & \\
\hline Herbivores & - & -0.31 & 0.39 & -0.09 & & \\
\hline Carnivores & & & & & $0.50^{* *}-0.30$ & -0.41 \\
\hline
\end{tabular}

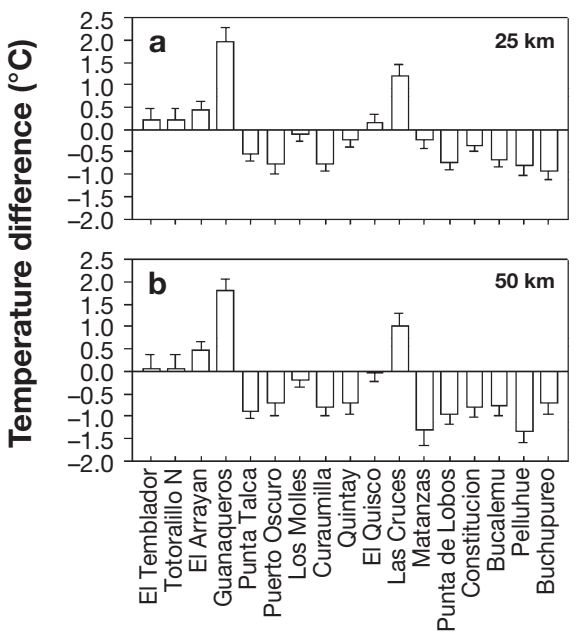

Fig. 5. Average differential in sea surface temperature (SST) for the 16 sites considered in the analysis obtained from 15 NOAA-AVHRR satellite images in spring to summer months of 1992/1993. A negative differential was interpreted as strong influence of coastal upwelling (focal point), as it indicates the presence of a cold coastal water mass relative to offshore SST. Sites considered affected by upwelling have shaded backgrounds in Figs. 2, 3 \& 4. Results are differences between inshore and ca $25 \mathrm{~km}$ offshore (a) and $50 \mathrm{~km}$ offshore (b). Error bars are standard errors from the 15 images

\section{Correlations among functional and trophic groups}

At the local scale (sites), strong and significant negative correlations were detected in the low intertidal zone between the abundance of kelps and crustose algae, and also between that of corticated and crustose algae (Table 3 ). In the mid-intertidal zone, the abundances of ephemeral and corticated algae, and those of barnacles and mussels showed significant negative correlations among sites (Table 3). Consumer versus resource abundance showed weaker but significant correlations in the low intertidal zone, with herbivore density being negatively correlated to the cover of kelps and corticated algae (Table 3). A similarly weak, but significantly positive trend was observed between herbivore abundance and the cover of crustose algae in the low zone (Table 3). The only significant association between carnivore abundance, including Heliaster, and prey groups was a positive correlation with the cover of mussels in the mid-intertidal zone (Table 3). No other significant correlations were observed between functional group abundances across sites. 
Table 4. Summary of 1-way ANOVAs comparing the abundance of dominant functional groups between sites differentially influenced by upwelling. In all cases, the numerator degrees of freedom for the $F$-statistic was 1 . Bold type indicates significant differences at $\alpha=0.05$

\begin{tabular}{|lrrrc|}
\hline \multicolumn{1}{l}{ Source } & \multirow{2}{*}{ Residual df } & \multicolumn{1}{c}{ MS } & $F$ & $\mathrm{p}$ \\
\hline Low intertidal zone & & & & \\
Kelps & 13 & 3.6957 & 14.42 & $\mathbf{0 . 0 0 2 2}$ \\
Corticated algae & 13 & 0.3373 & 0.01 & 0.9557 \\
Crustose algae & 13 & 1233.2103 & 2.59 & 0.1317 \\
& & & & \\
Mid intertidal zone & & & & \\
Mussels & 14 & 900.2259 & 1.16 & 0.2993 \\
Corticated algae & 14 & 2463.2505 & 7.40 & $\mathbf{0 . 0 1 6 6}$ \\
Ephemeral algae & 14 & 3366.4743 & 13.27 & $\mathbf{0 . 0 0 2 7}$ \\
Crustose algae & 14 & 0.4797 & 0.04 & 0.8357 \\
Barnacles & 14 & 68.9335 & 1.66 & 0.2182 \\
& & & & \\
\hline
\end{tabular}

\section{Relationship to oceanographic features}

After satellite image analyses (Fig. 5), we classified 9 sites as directly influenced by coastal upwelling (shaded sites in Figs 2, $3 \& 4$ ), and 8 sites as only weakly affected by upwelling (the site was far from the focal point of upwelling). Due to variation in the pattern of temperature differential at different distances from the coast (difference at $25 \mathrm{~km}$ offshore was not significantly negative, but it was at $50 \mathrm{~km}$ ) and the lack of published studies describing the presence of coastal upwelling in the area, 1 site (Constitución, $\sim 35^{\circ} \mathrm{S}$ ) could not be classified in either of these groups with the available information. This site and the marine reserve (ECIM) were excluded from these analyses. The inclusion of Constitución in the statistical analyses reduced observed probabilities associated to $F$-ratios of ANOVA and strengthened all significance tests. In the low intertidal zone, primary cover of kelps was significantly higher at sites directly influenced by upwelling (Table 4). In the mid-intertidal zone, sites directly influenced by upwelling had significantly higher cover of corticated algae, while ephemeral algae showed a significantly lower cover (Table 4). The abundances of other algal functional groups, sessile filterfeeders (cover of mussels and barnacles), herbivores and carnivores were not significantly different between sites with different influences of upwelling.

We examined the geographical structure of significant regional trends in abundance using LOWESS smoothing. The functional groups showing significant associations with SST were kelps and crustose algae in the low intertidal zone, and mussels and ephemeral algae in the mid-intertidal zone. We detected mainly 3 distinct geographical trends. Although kelps and mussels showed southward increases in abundance, they displayed different geographical response patterns. The locally weighted smoother showed a gradual southward increase in kelps (Fig. 6a), while a sudden drop in abundance was evident for mussels north of $32^{\circ} \mathrm{S}$ (i.e. $14.5^{\circ} \mathrm{C}$; Fig. 6b). A different response was observed for crustose algae in the low intertidal zone, which showed an asymptotically increasing response to temperature (Fig. 6c), reaching maximal cover at $33^{\circ} \mathrm{S}$ (i.e. $13.5^{\circ} \mathrm{C}$ ). Ephemeral algae in the mid-intertidal zone shared the positive response in cover associated with increasing temperature, but showed a much smoother trend (Fig. 6d). No other clear geographical patterns in abundance were detected in any other functional group examined.

\section{DISCUSSION}

The results presented above represent the first quantitative description of intertidal communities over large spatial scales along the coast of central Chile. This intertidal system has been the subject of many experimental studies, but the great majority of them

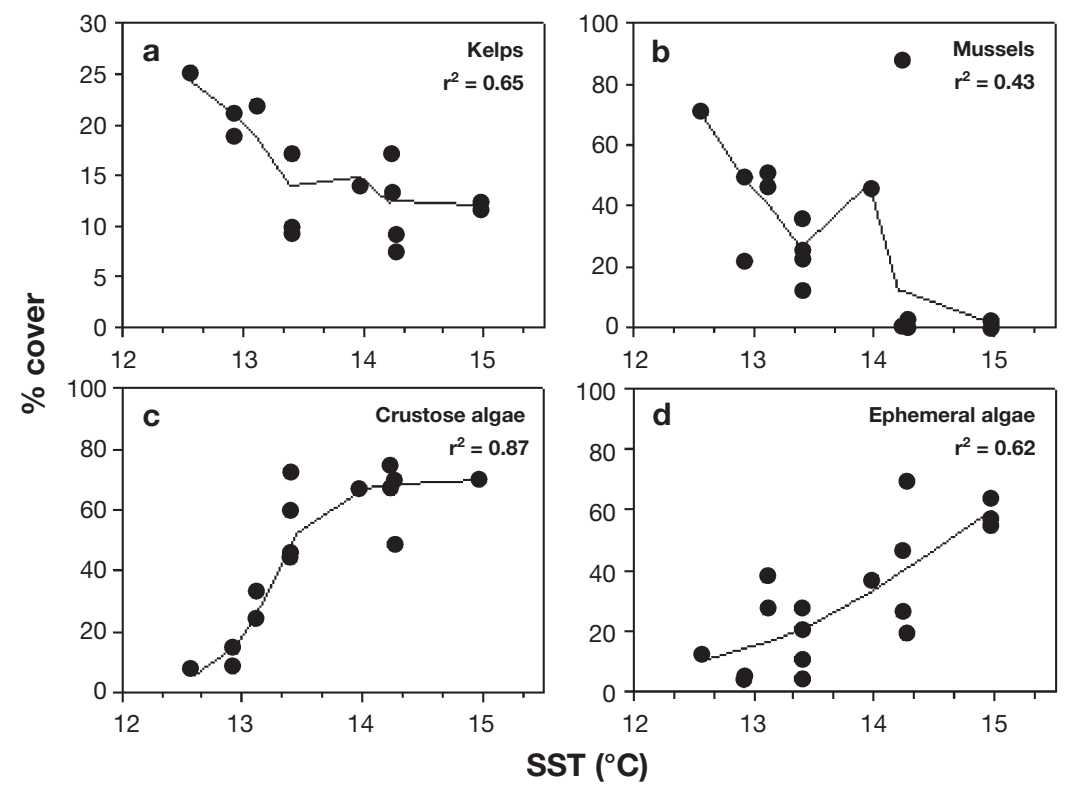

Fig. 6. Scatterplots of sea surface temperature (SST) and sessile functional group abundances. A LOWESS smoother (tension $=0.55$ ) describes the variation in abundance relative to SST (i.e. position of sites along the geographic gradient examined): (a) kelps and (c) crustose algae, low intertidal zone functional groups; (b) mussels and (d) ephemeral algae, mid-intertidal zone functional groups. The $\mathrm{r}^{2}$ value provided corresponds to the fit of the LOWESS model 
have been restricted to a few sites in the central portion of the region encompassed by this study (Camus 1998). The patterns presented here show that the intertidal communities are not a homogeneous system within central Chile, but rather include directional heterogeneity in the abundance of dominant sessile functional groups, such as kelps and mussels. In what follows, we discuss patterns of functional group abundance in relation to current ideas about the role of species interactions and oceanographic processes in regulating benthic community structure. This analysis provides testable hypotheses about community regulation and, we hope, will stimulate the necessary research to determine how benthic systems are coupled to nearshore oceanography.

\section{Correlations among functional groups}

Correlations between abundances of functional groups across sites provide insight into interspecific interactions, such as competition and predation, which may be limiting. For instance, the significant negative correlations found among dominant space occupiers of the low intertidal zone support the idea that competition for space may constrain the abundance of some functional groups, contributing to among-site variability. Corticated algae and kelp holdfast cover were inversely correlated with the cover of crustose algae, which is likely a consequence of the competitive interactions that have been experimentally demonstrated at a few sites in central and northern Chile (Ojeda \& Santelices 1984, Camus 1994). The existence of significant negative correlations between corticated and ephemeral algae in the mid-intertidal zone may not be the result of direct spatial competition, however. The fact that these functional groups tend to be abundant over different portions of the geographic gradient (i.e. different direction in regional trends) suggests that they respond differently to the wide range of environmental stress (Littler \& Littler 1980) present across the region. Alternatively, this pattern could be the result of a reversal in competitive hierarchies as ephemeral algae withstand environmental stress (i.e. heat stress, desiccation, nutrient limitation) far better than other algal functional groups (Gaines \& Lubchenco 1982, Steneck \& Dethier 1994). Experiments examining the physiological responses of these functional groups across the region would prove useful for evaluating these hypotheses.

As expected from previous experimental manipulations demonstrating negative competitive interactions between barnacles and mussels in the mid-intertidal zone (Paine et al. 1985, Navarrete \& Castilla 1990b), a significant negative correlation was detected between these groups. However, the strength of the overall correlation between mussels and barnacles across the entire region was low. To some extent, weak negative correlations could occur because our cover estimates include both primary and secondary substrates (e.g. barnacles settled on mussel shells). However, it seems that the strength of the negative association is weak mostly because the dramatic decline in mussel cover north of Los Molles was not matched by a concomitant increase in barnacle abundance in the mid-zone, as expected from competitive release. If only sites south of Los Molles are considered, the strength of the negative correlation improves and becomes highly significant $(\mathrm{r}=-0.62, \mathrm{p}<0.001)$. This suggests that the area of Los Molles, about $32^{\circ} \mathrm{S}$, represents an important break in the strength of at least some biological interactions. This hypothesis may be tested by setting up similarly designed competition experiments at a few selected sites north and south of Los Molles, to quantify the intensity of species interactions (e.g. Berlow et al. 1999, Leonard 2000).

Significant negative correlations between herbivore abundance and the cover of corticated algae and kelp holdfasts suggest that herbivory may play an important role in determining among-site variability in the abundance of algal groups. Experiments conducted at selected sites in southern, central and northern Chile support this explanation (Jara \& Moreno 1984, Oliva \& Castilla 1986, Santelices 1990, Camus 1994). The possibility of strong consumer-resource interactions is further reinforced by the significant positive correlation in the low intertidal zone between herbivore abundance and the cover of crustose algae, mostly calcified forms, which characteristically dominate high herbivory environments (Gaines \& Lubchenco 1982, Santelices \& Ojeda 1984, Steneck \& Dethier 1994). In contrast to the low zone, only weak non-significant correlations were observed at mid-intertidal levels between herbivore abundance and algal functional groups. Lack of strong correlations may be the result of mussel dominance at most sites, a functional group which excludes macroalgae from the primary substratum, or the fact that a high proportion of the macroalgal abundance at this tidal level was accounted for by secondary cover (e.g. on mussels or barnacles), which may provide a refuge from herbivores. In addition, the high herbivore numbers per unit area at mid-intertidal levels are primarily species of small body size, which may not have strong effects on macroalgae.

Lack of significant negative correlations between the abundance of carnivores and of herbivores, mussels or barnacles might suggest that interactions between these groups are not strong along the central Chilean coast. At present, there are no experimental studies testing the effects of top predators on mobile herbi- 
vores in order to evaluate the interaction between these 2 groups. However, several experimental studies conducted in central Chile have shown strong effects of predators on mussels and barnacles (Paine et al. 1985, Castilla \& Paine 1987, Durán \& Castilla 1989, present paper), which would be expected to generate negative correlations across sites. Nevertheless, predation effects may be stronger in the lower portion of the intertidal zone, and predators could very well be responsible for the near absence of mussel beds and scarce barnacle cover at low tidal levels throughout the region, which would not be evidenced as negative correlations among sites.

Significant positive correlations between carnivores and mussels at mid tidal levels seem primarily due to abundant predatory crabs (Acanthocyclus spp.), which use mussel beds as refuges (Navarrete \& Castilla 1990a, authors' pers. obs.). These results suggest that regional patterns of mussel abundance can drive patterns of other functional groups and emphasize the importance of biogenic structure as refuges in marine ecosystems (e.g. Witman 1985).

Patterns of abundance of individual functional groups within the marine reserve (ECIM site; solid bars in Figs 2, 3 \& 4) highlight the importance of humans as structuring agents in the central Chilean intertidal zone (Castilla 1999). Permanent exclusion of recreational and subsistence food gatherers from the reserve has led to a landscape in which the low intertidal zone shows reduced cover of corticated algae (Fig. 2). In contrast, the mid-zone appears dominated by crustose algae and bare rock, with large reductions of corticated algae and particularly mussel cover (Fig. 3). These patterns suggest that the effects of human predation are more intense in the mid-intertidal zone, which could indirectly affect the strength of both herbivory and carnivory throughout central Chile. For example, human predation on large herbivores (e.g. adult fissurellids; Oliva \& Castilla 1986) in the mid-intertidal zone may provide an alternative explanation for the lack of strong correlation between herbivores and algal functional groups across sites. Additionally, the continuous removal of the large muricid gastropod Concholepas by humans has undoubtedly altered the intensity of predation across the region, but its consequences on regional patterns of the landscape still need to be assessed through experimental manipulations.

\section{Relationship to oceanographic features}

Beyond among-site variability, some of which can be reasonably explained by biological interactions, we observed important variation of community structure that may be associated with some of the prevailing oceanographic features along central Chile. These associations were expressed as smooth gradients across several degrees of latitude, or as abrupt changes occurring within one degree of latitude.

The latitudinal gradient in SST accounted for a considerable amount of the variance in the abundance of kelps, as well as crustose and ephemeral algae across the entire region. A testable hypothesis is that kelp performance is significantly affected by temperature. Numerous studies have shown that low temperature can positively affect reproduction, propagule survival, and growth of kelps (Lüning \& Neushul 1978, Peters \& Breeman 1993, Dayton et al. 1999), which could account for the observed increase in kelp abundance toward higher latitudes. Studies conducted at a fixed location in the Southern California Bight have shown a strong negative correlation between seawater temperature and nitrate concentrations (e.g. Dayton et al. 1999). If this relationship applies over latitudinal gradients, then higher nutrient concentrations are expected toward the south of our study region, which, in turn, should favor faster kelp growth rates (e.g. Fujita et al. 1989). The sharp decline in cover of crustose algae in the low intertidal zone southward of Matanzas may be related to the significant southward increase in the abundance of kelps and corticated algae. Competitive interactions may also be affected by periodic sand burial (Airoldi 2000), which becomes more common south of about $35^{\circ} \mathrm{S}$ (Santelices 1990, authors' pers. obs.)

Significant differences in the abundance of key algal functional groups in relation to the presence or absence of strong upwelling provides evidence for the importance of mesoscale oceanographic features in this system. As expected from models of bottom-up regulation of benthic communities (e.g. Menge et al. 1997a,b, Nielsen 1998, Leonard et al. 1999), we observed increased abundance of corticated algae and kelps at sites with stronger upwelling than at sites only indirectly affected by upwelled waters, probably as a response to increased nutrient availability (Fujita et al. 1989, Nielsen 1998). The concomitant decline in ephemeral algae in the mid-zone of strong upwelling sites, where corticated algae are abundant (see Fig. 2b $\& 3 b)$, suggests that competitive interactions between these groups can be modified by nutrient availability, but this proposition awaits experimental testing. Contrary to predictions from bottom-up models (e.g. Menge et al. 1997a, Leonard et al. 1999), we did not observe the predicted increase in the abundance of filter-feeders at sites of stronger upwelling. Our results suggest that in this benthic system, the phytoplankton to filter-feeder pathway is more complex or less predictable than the pathway from nutrients to macroalgae. Indeed, there exists evidence suggesting that 
phytoplankton biomass, and therefore food availability, for filter-feeders is lower at focal points of upwelling than at areas some distance away from the recently upwelled waters (e.g. Smith et al. 1966, Wroblewski 1977). If this is the case along the Chilean coast, then phytoplankton biomass would vary in complex patterns depending on the intensity of local upwelling and the distance downstream from an upwelling center. These propositions also await further studies and experimentation.

Abrupt changes in the abundance of mussels in the mid-intertidal zone at about $32^{\circ} \mathrm{S}$ suggest a similarly abrupt change in biological or environmental conditions. While numerous studies have demonstrated the strong influence of key predators such as Heliaster and Concholepas concholepas on mussel abundance (Castilla \& Durán 1985, Paine et al. 1985, Durán \& Castilla 1989), these predators do not exhibit important increases in abundance (or size, authors' pers. obs.) north of Los Molles (see Fig. 4c,d). Our direct observations and preliminary experiments also suggest that predation intensity on mussels is not significantly higher at our northern sites, so it is unlikely that predation is responsible for the abrupt geographic break in mussel cover. One potential explanation is the existence of basin-scale changes in the oceanographic conditions that determine the cross-shelf transport of larvae back to the adult habitat. Connolly \& Roughgarden (1998) have suggested that the equatorward decrease of mussel abundance along the northeastern Pacific coast is the result of a progressive increase in offshore, wind-driven Ekman transport, which affects the rates of larval return to the benthic habitat. A similar difference in larval delivery rates could be responsible for the low mussel abundance north of $32^{\circ} \mathrm{S}$. There, the continental shelf abruptly narrows (Strub et al. 1998, Thomas 1999), potentially reducing coastal water retention. These physical processes should lead to overall lower mussel recruitment rates at sites north of Los Molles. A recent remote sensing study off the central coast of Chile has evidenced a strikingly similar break in chlorophyll a concentration at about $32^{\circ} \mathrm{S}$ (Thomas 1999), which is also attributed to basin-scale changes in oceanographic regimes within the region. Breaks in the offshore chlorophyll a concentration also suggest the hypothesis of food limitation as an alternative to, or in combination with, the mussel recruitment limitation north of $32^{\circ} \mathrm{S}$. These hypotheses may be tested by quantifying recruitment rates, survival and growth of mussels at sites south and north of Los Molles. The actual oceanographic processes responsible for the coupled breaks in benthic and pelagic systems should be a focus of intense research in the future, for they might represent the driving forces behind abrupt biogeographic discontinuities in coastal areas such as Point Conception (USA), the Cape Peninsula (South Africa) and north of Los Molles (Chile) (Briggs 1974, Castilla 1981, Bustamente \& Branch 1996).

This study represents the first quantitative description of the intertidal assemblages of the southeastern Pacific and allows a preliminary evaluation of the importance of local ecological processes and how they are modulated by oceanographic features. Further studies on the nearshore oceanography of the region and local experiments contrasting distant sites, particularly north and south of about $32^{\circ} \mathrm{S}$, are necessary in order to evaluate causal processes. Based on the patterns presented we suggest that local processes, such as competition and predation, should vary across the region. Some of these processes may change in a smooth, gradual fashion, detectable only when comparing sites toward the extremes of the region, but some are expected to change in an abrupt manner when comparing sites across breaks (i.e. south and north of about $32^{\circ} \mathrm{S}$ ). Characterization of local community interactions within a variable environmental framework is essential for interpreting results of studies conducted at single or few sites. We hope that this analysis will inspire further experimental studies to develop forecasts of community responses to large-scale environmental changes.

Acknowledgements. We are indebted to a number of friends and colleagues who enthusiastically helped us in the long hours of field work, including C. Espoz, R. Finke, D. Kaplan, K. Nielsen, Zahna Neskouwi, A. Sotomayor, R. Venegas, E. Wieters, H. Zeballos, ball2 and others. Reviews by J. C. Castilla, C. Espoz and M. Fernández and comments by the editor greatly improved an earlier version of the manuscript. F.S. acknowledges post-doctoral support from an IAI-ISP-II grant to S.A.N. Financial support for the initial surveys conducted in July 1997 and 1998 was provided by an IAI-ISP-II grant, Fundación Andes, and particularly from FONDECYT \#197/1263 to S.A.N. Considerable expansion of the latitudinal survey was possible thanks only to a grant from FONDAP O. \& B.M. Ecología y Conservación \#3 to S.A.N., for which we are most grateful. S.A.N. and S.D.G. acknowledge the Andrew Mellon Foundation for grants making these collaborations possible.

\section{LITERATURE CITED}

Airoldi L (2000) Effects of disturbance, life histories, and overgrowth on coexistence of algal crusts and turfs. Ecology 81:798-814

Alexander SE, Roughgarden J (1996) Larval transport and population dynamics of intertidal barnacles: a coupled benthic/oceanic model. Ecol Monogr 66:259-275

Archambault P, Bourget E (1996) Scales of coastal heterogeneity and benthic intertidal species richness, diversity and abundance. Mar Ecol Prog Ser 136:111-121

Archambault P, McKindsey CW, Bourget E (1999) Large scale shoreline configuration influences phytoplankton concentration and mussel growth. Estuar Coast Shelf Sci 49: 193-208 
Berlow EL, Navarrete SA, Briggs CJ, Menge BA, Power ME (1999) Quantifying variation in the strength of species interactions. Ecology 80:2206-2224

Bernal PA, Robles FL, Rojas O (1982) Variabilidad física y biológica en la región meridional del sistema de corrientes Chile-Perú. In: Castilla JC (ed) Bases biológicas para el uso y manejo de recursos naturales renovables: recursos biológicos marinos. Monografías Biológicas, Vol. 2, Pontificia Universidad Católica de Chile, Santiago, p 75-102

Bertness MD, Gaines SD, Bermudez D, Sanford E (1991) Extreme spatial variation in the growth and reproductive output of the acorn barnacle Semibalanus balanoides. Mar Ecol Prog Ser 75:91-100

Bosman AL, Hockey PAR, Siegfried WR (1987) The influence of coastal upwelling on the functional structure of rocky intertidal communities. Oecologia (Berl) 72:226-232

Botsford LW, Castilla JC, Peterson CH (1997) The management of fisheries and marine ecosystems. Science 277: 509-515

Branch GM, Moreno CA (1994) Intertidal and subtidal grazers. In: Sigfried WR (ed) Rocky shores: exploitation in Chile and South Africa. Springer-Verlag, Berlin, p 75-100

Brattström H, Johänssen A (1983) Ecological and regional zoogeography of the marine benthic fauna of Chile. Sarsia 68:289-339

Briggs JC (1974) Marine biogeography. McGraw-Hill, New York

Brown JH, Lomolino MV (1998) Biogeography, 2nd edn. Sinauer Associates Inc, Sunderland, MA

Bustamante RH (1997) The influences of physical factors on the distribution and zonation patterns of South African rocky-shore communities. S Afr J Mar Sci 18:119-136

Bustamante RH, Branch GM (1996) Large scale patterns and trophic structure of southern African rocky shores: the role of geographic variation and wave exposure. J Biogeogr 23:339-351

Bustamante RH, Branch GM, Eekhout S (1995a) Maintenance of an exceptional intertidal grazer biomass in South Africa: subsidy by subtidal kelps. Ecology 76:2314-2329

Bustamante RH, Branch GM, Eekhout S, Robertson B, Zoutendyk P, Schleyer M, Dye A, Hanekon N, Keats D, Jurd M, McQuaid C (1995b) Gradients of intertidal primary productivity around the coast of South Africa and their relationship with consumer biomass. Oecologia (Berl) 102:189-201

Camus PA (1994) Recruitment of the intertidal kelp Lessonia nigrescens Bory in northern Chile: successional constraints and opportunities. J Exp Mar Biol Ecol 184:171-181

Camus PA (1998) Estructura espacial de la diversidad en ensambles sésiles del intermareal de Chile centro-norte: la diversidad local como un resultado de determinantes de multiescala. PhD thesis, Pontificia Universidad Católica de Chile, Santiago

Castilla JC (1981) Perspectivas de investigación en estructura y dinámica de comunidades intermareales rocosas de Chile central. II. Depredadores de alto nivel trófico. Medio Ambiente 5:190-215

Castilla JC (1993) Humans: capstone strong actors in the past and present coastal ecological play. In: McDonnell MJ, Pickett STA (eds) Humans as components of ecosystems: the ecology of subtle effects and populated areas. Springer-Verlag, New York, p 158-162

Castilla JC (1999) Coastal marine communities: trends and perspectives from human-exclusion experiments. Trends Ecol Evol 14:280-283

Castilla JC, Durán LR (1985) Human exclusion from the rocky intertidal zone of central of central Chile: the effects on Concholepas concholepas (Gastropoda). Oikos 45:391-399
Castilla JC, Paine RT (1987) Predation and community organization on eastern Pacific, temperate zone, rocky intertidal shores. Rev Chil Hist Nat 60:131-151

Connell JH (1974) Field experiments in marine ecology. In: Mariscal R (ed) Experimental marine biology. Academic Press, New York

Connolly SR, Roughgarden J (1998) A latitudinal gradient in northeast Pacific intertidal community structure: evidence for an oceanographically based synthesis of marine community theory. Am Nat 151:311-326

Connolly SR, Roughgarden J (1999a) Increased recruitment of northeast Pacific barnacles during the 1997 El Niño. Limnol Oceanogr 44:466-469

Connolly SR, Roughgarden J (1999b) Theory of marine communities: competition, predation, and recruitment-dependent interaction strength. Ecol Monogr 69:277-296

Dayton PK, Tegner MJ, Edwards PB, Riser KL (1999) Temporal and spatial scales of kelp demography: the role of oceanographic climate. Ecol Monogr 69:219-250

Dethier MN, Graham ES, Cohen S, Tear LM (1993) Visual versus random-point percent cover estimations: 'objective' is not always better. Mar Ecol Prog Ser 96:93-100

Durán LR, Castilla JC (1989) Variation and persistence of the middle intertidal community of central Chile, with and without human harvesting. Mar Biol 103:555-562

Farrell TM, Bracher D, Roughgarden J (1991) Cross-shelf transport causes recruitment to intertidal populations in central California. Limnol Oceanogr 36:279-288

Fonseca RT, Farías M (1987) Estudio del proceso de surgencia en la costa chilena utilizando percepción remota. Investig Pesq (Chile) 34:33-46

Fujita RM, Wheeler PA, Edwards RL (1989) Assessment of macroalgal nitrogen limitation in a seasonal upwelling region. Mar Ecol Prog Ser 53:293-303

Gaines SD, Bertnes MD (1992) Dispersal of juveniles and variable recruitment in sessile marine species. Nature 360:579-580

Gaines SD, Lubchenco J (1982) A unified approach to marine plant-herbivore interactions. II. Biogeography. Annu Rev Ecol Syst 13:111-138

Gaines SD, Roughgarden J (1985) Larval settlement rate: a leading determinant of structure in an ecological community of the marine intertidal zone. Proc Natl Acad Sci USA 82:3707-3711

Goes JI, Saino T, Oaku H, Ishizaka J, Wong CS, Noriji Y (2000) Basin scale estimates of sea surface nitrate and new production from remotely sensed sea surface temperature and chlorophyll. Geophys Res Lett 27:1263-1266

Hill AE, Hickey BM, Shillington FA, Strub PT, Brink KH, Barton ED, Thomas AC (1998) Eastern ocean boundaries. Coastal segment. The Sea 11:29-67

Jara HF, Moreno CA (1984) Herbivory and structure in a mid littoral rocky community: a case in southern Chile. Ecology 65:28-38

Johnson DR, Fonseca T, Sievers H (1980) Upwelling in the Humboldt Coastal Current near Valparaíso, Chile. J Mar Res 38:1-15

Legendre P, Legendre L (1998) Numerical ecology, 2nd edn. Elsevier Science, Amsterdam

Leonard GH (2000) Latitudinal variation in species interactions: a test in the New England rocky intertidal zone. Ecology 81:1015-1030

Leonard GH, Levine JM, Schmidt PR, Bertness MD (1999) Flow-driven variation in intertidal community structure in a Maine estuary. Ecology 79:1395-1411

Levin SA (1992) The problem of pattern and scale in ecology. Ecology 73:1943-1967 
Littler MM, Littler DS (1980) The evolution of thallus form and survival strategies in benthic marine macroalgae: field and laboratory tests of a functional form model. Am Nat 116:25-44

Longhurst A (1998) Ecological geography of the sea. Academic Press, San Diego

Lubchenco J, Gaines SD (1981) A unified approach to marine plant-herbivore interactions. I. Populations and communities. Annu Rev Ecol Syst 12:405-437

Lüning K, Neushul M (1978) Light and temperature demands for growth and reproduction in laminarian gametophytes in southern and central California. Mar Biol 45:297-309

Menge BA (1976) Organization of the New England rocky intertidal community: role of predation, competition, and environmental heterogeneity. Ecol Monogr 46:355-393

Menge BA (1992) Community regulation: under what conditions are bottom-up factors important on rocky shores? Ecology 73:755-765

Menge BA, Olson AM (1990) Role of scale and environmental factors in regulation of community structure. Trends Ecol Evol 5:52-57

Menge BA, Berlow EL, Blanchette C, Navarrete SA, Yamada SB (1994) The keystone species concept: variation in interaction strength in a rocky intertidal habitat. Ecol Monogr 64:249-286

Menge BA, Daley BA, Wheeler PA, Dahlhoff E, Sanford E, Strub PT (1997a) Benthic-pelagic links and rocky intertidal communities: bottom-up effects on top-down control? Proc Natl Acad Sci USA 94:14530-14535

Menge BA, Daley BA, Wheeler PA, Strub PT (1997b) Rocky intertidal oceanography: an association between community structure and nearshore phytoplankton concentration. Limnol Oceanogr 42:57-66

Montecino V, Pizarro G, Quiroz D (1996) Dinámica fitoplanctónica en el sistema de surgencia frente a Coquimbo $\left(30^{\circ} \mathrm{S}\right)$ a través de la relación funcional entre fotosíntesis e irradianza (P-I). Gayana Oceanogr 4:139-151

Montecinos A, Balbontin F (1993) Indices de surgencia y circulación superficial del mar: implicancias biológicas en un área de desove de peces entre Los Vilos y Valparaíso, Chile. Rev Biol Mar 28:133-150

Moreno CA, Lunecke KM, López MI (1986) The response of an intertidal Concholepas concholepas (Gastropoda) population to protection from Man in southern Chile and effects on benthic assemblages. Oikos 46:359-364

Moreno CA, Asencio G, Duarte WE, Marin V (1998) Settlement of the muricid of Concholepas concholepas and its relationship with El Niño and coastal upwelling in Southern Chile. Mar Ecol Prog Ser 167:171-175

Navarrete SA (1996) Variable predation: effects of whelks on a mid intertidal successional community. Ecol Monogr 66: 301-322

Navarrete SA, Castilla JC (1990a) Resource partitioning between intertidal predatory crabs: interference and refuge utilization. J Exp Mar Biol Ecol 143:101-129

Navarrete SA, Castilla JC (1990b) Barnacle walls as mediators of intertidal mussel recruitment: effects of patch size on the utilization of space. Mar Ecol Prog Ser 68:1113-119

Navarrete SA, Menge BA (1996) Keystone predation: interactive effects of two predators in their main prey. Ecol Monogr 66:409-429

Neter J, Kutner MH, Nachtsheim CJ, Wasserman W (1996) Applied linear regression models. Irwin, Inc, Chicago

Nielsen KJ (1998) Bottom-up and top-down forces in tidepools: the influence of nutrients, herbivores, and wave exposure on community structure. PhD thesis, Oregon State University, Corvallis
Ojeda FP, Santelices B (1984) Ecological dominance of Lessonia nigrescens (Phaeophyta) in central Chile. Mar Ecol Prog Ser 19:83-91

Oliva D, Castilla JC (1986) The effect of human exclusion on the population structure of key-hole limpets F. crassa and F. limbata on the coast of central Chile. Mar Ecol 7: 201-217

Padilla DK, Allen BJ (2000) Paradigm lost: reconsidering functional form and group hypothesis in marine ecology. J Exp Mar Biol Ecol 250:207-221

Paine RT (1966) Food web complexity and species diversity. Am Nat 100:65-75

Paine RT (1974) Intertidal community structure: experimental studies on the relationship between a dominant competitor and its principal predator. Oecologia (Berl) 15:93-120

Paine RT, Castilla JC, Cancino J (1985) Perturbation and recovery patterns of starfish-dominated intertidal assemblages in Chile, New Zealand, and Washington State. Am Nat 125:679-691

Peters AF, Breeman AM (1993) Temperature tolerance and latitudinal range of brown algae from temperate Pacific South America. Mar Biol 115:143-150

Ricklefs RE (1987) Community diversity: relative roles of local and regional processes. Science 235:167-171

Roughgarden J, Gaines SD, Possingham H (1988) Recruitment dynamics in complex life cycles. Science 241: $1460-1466$

Santelices B (1980) Phytogeographic characterization of the temperate coast of Pacific South America. Phycologia 19: $1-12$

Santelices B (1990) Algas marinas de Chile. Ediciones Universidad Católica de Chile, Santiago

Santelices B, Ojeda FP (1984) Recruitment, growth and survival of Lessonia nigrescens (Phaeophyta) at various tidal levels in exposed habitats of central Chile. Mar Ecol Prog Ser 19:73-82

SHOA (Servicio Hidrografico y Oceanográfico de la Armada) (1996) Atlas oceanográfico de Chile. SHOA, Valparaiso

Smith RL, Pattullo JG, Lane RK (1966) An investigation of the early stage of upwelling along the Oregon coast. J Geophys Res 71:1135-1140

Soto R (1996) Estructura gremial de un ensamble de depredadores de la zona intermareal rocosa en Chile central. Investig Mar Univ Catol Valpso 24:97-105

Sousa WP, Schroeter SC, Gaines SD (1981) Latitudinal variation in intertidal algal community structure: the influence of grazing and vegetative propagation. Oecologia (Berl) 48:297-307

Steneck RS, Dethier MN (1994) A functional approach to the structure of algal dominated communities. Oikos 69: 476-498

Strub PT, Mesías JM, Montecino V, Rutllant J, Salinas S (1998) Coastal ocean circulation off western South America. The Sea 11:273-313

Thomas AC (1999) Seasonal distributions of satellite-measured phytoplankton pigment concentration along the Chilean coast. J Geophys Res 104:25877-25890

Vásquez JA, Camus PA, Ojeda FP (1998) Diversidad, estructura y funcionamiento de ecosistemas costeros rocosos del norte de Chile. Rev Chil Hist Nat 71:479-499

Witman J (1985) Refuges, biological disturbance, and rocky subtidal community structure in New England. Ecol Monogr 55:421-445

Wroblewski JS (1977) A model of phytoplankton plume formation during variable Oregon upwelling. J Mar Res 35: $357-394$

Submitted: April 18, 2000; Accepted: April 24, 2001

Proofs received from author(s): December 5, 2001 